\title{
Daphnia diversity in water bodies of the Po River Basin
}

\author{
Silvia MARKOVÁ, ${ }^{1}$ Catia MAURONE, ${ }^{2}$ Erica RACCHETTI, ${ }^{2}$ Marco BARTOLI, ${ }^{2}$ Valeria ROSSI $^{2 *}$ \\ ${ }^{1}$ Laboratory of Molecular Ecology, Institute of Animal Physiology and Genetics, Academy of Sciences of the Czech Republic, \\ Rumburská 89, 27721 Liběchov, Czech Republic; ${ }^{2}$ Department of Life Sciences, University of Parma, Viale Usberti 11/A, 43124 Parma, \\ Italy \\ *Corresponding author: valeria.rossi@unipr.it
}

\begin{abstract}
Shallow water bodies dominate the areal extent of continental waters and host a proportion of biodiversity higher than the percentage of Earth's surface they cover. Daphnia is a key component of small aquatic ecosystems food webs. Here we present the result of a survey in 24 ponds located in the core of Po river Basin, to assess the actual spreading of Daphnia species in one of the most productive areas of the Northern hemisphere. By using diagnostic genetic markers (12S rRNA and ND5 genes) we identified five Daphnia species: D. ambigua, D. curvirostris, D. longispina, D. obtusa and D. pulex in fourteen ponds. Additional analyses of two nuclear genes ( $L d h A$ and Rab4) revealed that $D$. pulex in the study area is native European strain. In opposite, $D$. ambigua shared haplotype with the North-Eastern American lineage that was introduced to Europe by long-distance dispersal. In the Po river Basin we identified a highly divergent lineage of $D$. longispina group that formed a clade with individuals from northern European Russia and might represent a new Daphnia species. Daphnia species in the Cremona province have European origin, except for D. ambigua which is a North American species spreading across Europe. Future attention will require monitoring of invasive species, particularly D. ambigua and the North American invasive clone of $D$. pulex that is already present in Northern Italy.
\end{abstract}

Key words: Genetic diagnostic markers; invasive species; genetic differentiation; D. pulex complex; ponds.

Received: June 2016. Accepted: November 2016.

\section{INTRODUCTION}

Although freshwater ecosystems cover less than $1 \%$ of the earth's surface, they host almost $10 \%$ of the world's species that are directly supported through a wide range of habitats including running water in rivers, standing waters of lakes, ponds, pools and swamps and areas of ephemeral wetlands (Loh and Wackernagel, 2004; Feld et al., 2016). In recent years much attention has been paid to large lakes and rivers while small lakes and ponds that dominate the areal extent of continental waters have been completely ignored (Downing, 2010). However, small aquatic ecosystems play a major role in global cycles and in the Earth's most pressing environmental problems (Downing, 2010). In addition, permanent or temporary small, shallow water bodies offer a powerful potential for studies of ecology, evolutionary and conservation biology and provide high contribution to regional biodiversity (De Meester et al., 2005). The organisms that colonise ponds and pools have evolved specific adaptations to deal with often extreme, disturbed, short hydro-period habitats, such as very effective spatial and temporal dispersal mechanisms (Ripley and Simovich, 2009). Furthermore, shallow water bodies are highly sensitive to climate warming and human activities due to substantial changes in thermal and hydrological regimes that play important role in freshwa- ter biodiversity decline (Scheffer et al., 2001; Dudgeon et al., 2006; Mitchell et al., 2005; Meerhoff et al., 2007; Feuchtmayr et al., 2009; Landkildehus et al., 2014). In Europe, up to $80 \%$ of the land is intensively used for settlements, infrastructure and production systems and aquatic biodiversity is probably impoverished accordingly (Feld et al., 2016).

Many of the cladoceran taxa recognized by traditional taxonomists are actually an admixture of genetically divergent species (Hebert and Wilson, 1994; Schwenk et al., 2000). Now, the application of molecular tools is fundamental for the identification of new and cryptic species, for tracing distribution and dispersal of native and invasive species as well as for identification of hybrid taxa and their relatives (Pfenning and Schwenk, 2007). Furthering the study of freshwater zooplankton biodiversity by using techniques of molecular biology might help to reveal genetic diversity within and among species that could be otherwise hardly uncovered.

Cladocera, small aquatic crustaceans, are a key component of aquatic food webs. They inhabit a range of freshwater habitats throughout the world. Some genera, such as Daphnia, have been intensively studied over the past 250 years in different fields. Recently, the growing impact of climate change on inhabitants of the most vulnerable freshwater habitats, such small lakes and ponds, is undoubtedly 
starting to be appreciated. Climate change is forcing Daphnia species to adjust their ways and may cause adverse effects on species diversity by means of elimination and/or replacement of sensitive species/strains by less sensitive ones, shifts in food-web interactions, acclimation of species/strains to stress, selection of tolerant genotypes, and outcome of predator-prey interactions (Belfiore and Anderson, 2001; Hunter and Pyle, 2004; Sakamoto et al., 2006; Riessen et al., 2012; Vadadi-Fülöp et al., 2012; Vadadi-Fülöp and Hufnagel, 2014). Additionally, environmental change creates ecological space for non-native species that can often replace native species. Recent invasion of the American Daphnia lineage to Africa was followed by rapid and complete continent-wide displacement of indigenous African D. pulex Leydig, 1860 throughout its native range (Mergeay et al., 2006) and was already recorded in Sardinia and Piedmont (Northern Italy) (Fadda et al., 2011; Marková et al., 2013).

In a previous paper, we reported the occurrence of the D. pulex group in the permanent pond named bodrio del Pastore III, in the Po River Basin (Northern Italy) where it co-exists with $D$. longispina O. F. Müller, 1776 (Rossi et al., 2014). The presence of $D$. pulex in this area is important in the framework of conservation ecology. In fact, we have shown that it is the native European species instead of the invasive North American asexual clone (Rossi et al., 2015). Here we extend our research to 24 surrounding water bodies located in the Po river basin in the Cre- mona province that is one of the most productive areas of the Northern hemisphere (Bassanino et al., 2011). Because of intensive farming, this area is threatened by diffuse pollution that, together with climatic changes, is a major driver of changes in freshwater ecosystems of Cremona province. Our main objectives are: 1) to assess the actual spreading and genetic diversity of native $D$. pulex and other Daphnia species in the area; 2) to verify morphological identification of different Daphnia species by using diagnostic mitochondrial gene (12S rRNA); and 3) to assess species identity and origin of Daphnia belonging to the $D$. pulex complex based on mitochondrial (the ND5 gene) and nuclear phylogenies (Rab4 and $L d h A$ genes).

\section{METHODS}

The study place is located in the Cremona province where temporary pools and ponds, locally named bodri, originated by dramatic flooding events of the Po River (the largest Italian river with an annual mean discharge of 1500 $\mathrm{m}^{3} \mathrm{~s}^{-1}$ ) (Fig. 1). Erosive processes dig cone-shaped holes with depths up to 6-10 $\mathrm{m}$ and surface of some hundreds to some thousands $\mathrm{m}^{2}$. At the end of flooding periods, these small ponds remain isolated from the main river course and start evolving as newly formed shallow aquatic environments. They display pronounced water level fluctuations, associated to the Po river hydrometric level, aquifer, pre-

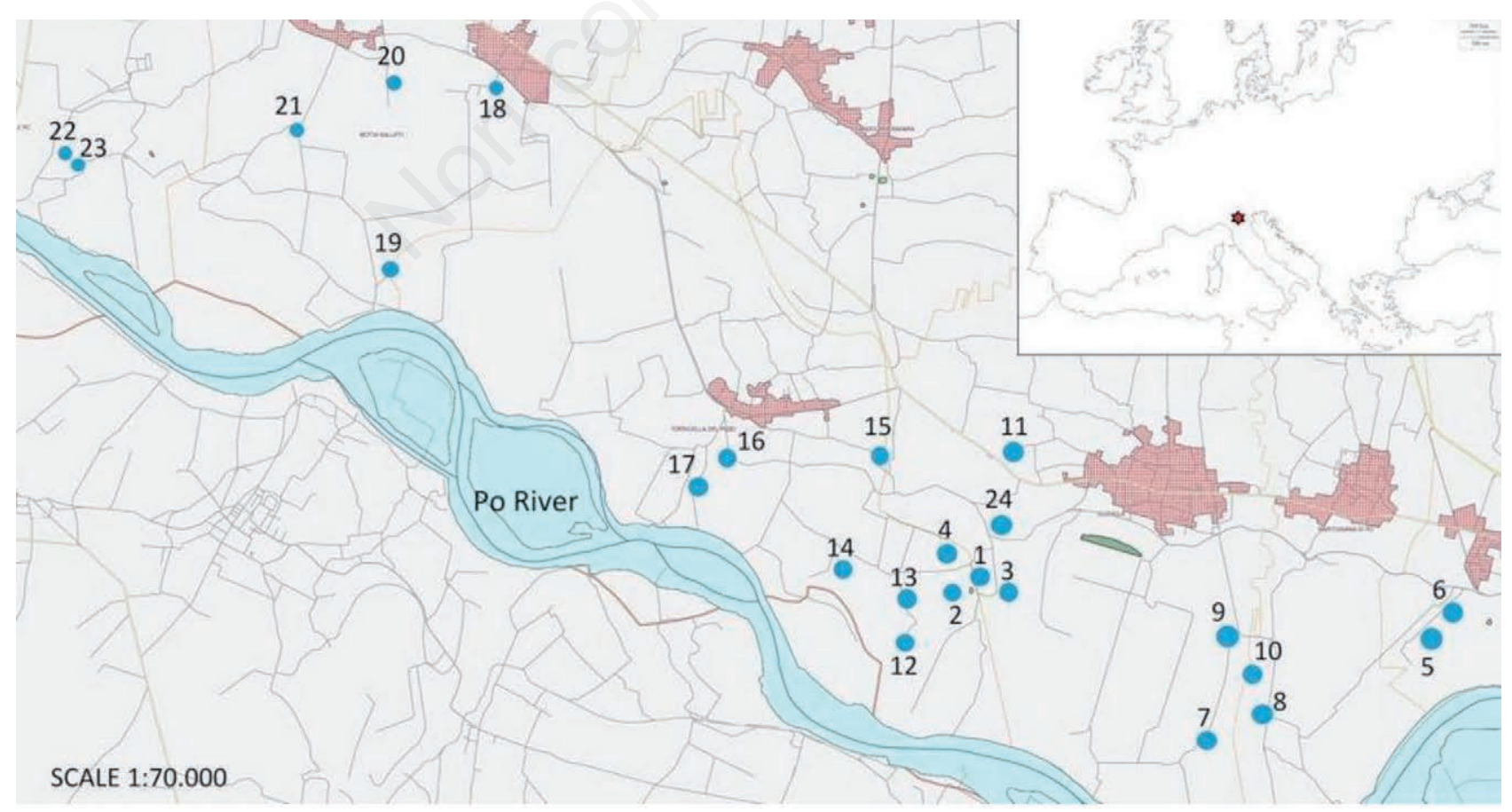

Fig. 1. Geographic location of the 24 sampling sites included in this study. 
cipitations, runoff, groundwater vertical migration and summer evaporation. In $450 \mathrm{~km}^{2}$ area, 61 water bodies were documented (AAVV, 1999). In this study, we focused on the occurrence of Daphnia species in 24 pools and ponds that were randomly selected in $200 \mathrm{~km}^{2}$ area (Fig. 1). Many of the studied water bodies originated before 1723 [date of the first census of bodri (AAVV, 1999)]; however, some are more recent (for details see Tab. 1). Most of the time ponds and pools are separated from each other without possibility of seasonal stream connections, but some accidental link may occur during heavy flooding. Their size varied between 1529 to $7070 \mathrm{~m}^{2}$; twelve of the 24 ponds contained fish and/or Chaoborus larvae [for details see Tab. 1; (AAVV, 1999)]. Each pond was sampled twice: first time between May and June 2014 and second time between June and July 2015.

Qualitative zooplankton samples were collected by $105 \mu \mathrm{m}$-mesh size plankton net. From 2 to 161 of water were filtered for each sample according to the water volume and depth. All samples were preserved in $95 \%$ ethanol. All cladocerans present in the sample were sorted under a stereomicroscope and were identified to genus level. Then, all Daphnia species were morphologically identified according to Margaritora (1985). A contingency table analysis was performed to test whether the presence of Daphnia was negatively associated with the presence of fish or Chaoborus larvae (Tab. 1). The frequency of samples with and without Daphnia was compared in relationship with the presence or the absence of predators.

To verify morphological identification of Daphnia species, one to 11 collected specimens per each locality were used in molecular analyses according to the number of species per site. In the locality where species replacement was recorded, Pastore III (Rossi et al., 2015), up to 5 individuals per species were analysed. To verify Daphnia species identity, $12 S$ rRNA diagnostic marker was used. Because determining the species within the $D$. pulex complex based only on morphological characters is notoriously difficult (Colbourne et al., 1998) and 12S rRNA gene is not a diagnostic marker for lineages within this complex, D. pulex complex, species from Po river Basin were analysed for an 711 base-pair (bp) long fragment

Tab. 1. Collection sites of Daphnia included in this study. For each site Area and Depth refer to maximum value.

\begin{tabular}{|c|c|c|c|c|c|c|c|c|}
\hline Code & Name & Latitude $\mathbf{N}$ & Longitude E & Area $\left(\mathrm{m}^{2}\right)$ & Depth (m) & Age & $\mathbf{F}$ & C \\
\hline 1 & Pastore III & $45^{\circ} 00^{\prime} 05^{\prime \prime}$ & $10^{\circ} 19^{\prime} 26^{\prime \prime}$ & 3130 & 6.3 & $1723-1870$ & 1 & 1 \\
\hline 2 & Pastore I & $45^{\circ} 00^{\prime} 00^{\prime \prime}$ & $10^{\circ} 19^{\prime} 13^{\prime \prime}$ & 2350 & 5.8 & $1935-1957$ & 1 & 1 \\
\hline 3 & Pastore IV & $45^{\circ} 00^{\prime} 01^{\prime \prime}$ & $10^{\circ} 19^{\prime} 46^{\prime \prime}$ & 3380 & 3.2 & $1723-1870$ & 1 & - \\
\hline 4 & Temporary pond & $45^{\circ} 00^{\prime} 12^{\prime \prime}$ & $10^{\circ} 19^{\prime} 23^{\prime \prime}$ & & & & - & - \\
\hline 5 & Bosco Braca & $44^{\circ} 59^{\prime} 41^{\prime \prime}$ & $10^{\circ} 23^{\prime} 18^{\prime \prime}$ & 2460 & 3.3 & 1935-1957 & - & - \\
\hline 6 & Cascina Pavarini & $40^{\circ} 59^{\prime} 50^{\prime \prime}$ & $10^{\circ} 23^{\prime} 29^{\prime \prime}$ & 3763 & 5.6 & 1968 & 1 & - \\
\hline 7 & Bosco Valloni & $44^{\circ} 59^{\prime} 06^{\prime \prime}$ & $10^{\circ} 21^{\prime} 20^{\prime \prime}$ & 1850 & 3.0 & $1723-1871$ & - & - \\
\hline 8 & San Giorgio & $44^{\circ} 59^{\prime} 15^{\prime \prime}$ & $10^{\circ} 21^{\prime} 54^{\prime \prime}$ & 2280 & 4.4 & $1723-1871$ & - & - \\
\hline 9 & Forche & $44^{\circ} 59^{\prime} 38^{\prime \prime}$ & $10^{\circ} 21^{\prime} 47^{\prime \prime}$ & 3140 & 3.2 & $1723-1870$ & - & - \\
\hline 10 & Martignana & $44^{\circ} 59^{\prime} 29^{\prime \prime}$ & $10^{\circ} 21^{\prime} 47^{\prime \prime}$ & 2230 & 5.3 & $1723-1871$ & - & - \\
\hline 11 & S. Mariamaddalena & $45^{\circ} 00^{\prime} 50^{\prime \prime}$ & $10^{\circ} 19^{\prime} 44^{\prime \prime}$ & 2280 & 1.8 & B 1723 & - & - \\
\hline 12 & Bosco Bodini & $44^{\circ} 59^{\prime} 42^{\prime \prime}$ & $10^{\circ} 18^{\prime} 47^{\prime \prime}$ & 1529 & 3.5 & $1957-1980$ & - & 1 \\
\hline 13 & Cascina Mortara & $44^{\circ} 59^{\prime} 59^{\prime \prime}$ & $10^{\circ} 18^{\prime} 50^{\prime \prime}$ & 2985 & 5.6 & 1723 & 1 & 1 \\
\hline 14 & Bosco Piazza & $45^{\circ} 00^{\prime} 09^{\prime \prime}$ & $10^{\circ} 18^{\prime} 18^{\prime \prime}$ & 3390 & 4.0 & $1723-1870$ & - & 1 \\
\hline 15 & Tavernelle & $45^{\circ} 00^{\prime} 51^{\prime \prime}$ & $10^{\circ} 18^{\prime} 37^{\prime \prime}$ & 2420 & 4.5 & B 1723 & - & 1 \\
\hline 16 & Vecchio & $45^{\circ} 00^{\prime} 50^{\prime \prime}$ & $10^{\circ} 17^{\prime} 18^{\prime \prime}$ & 7070 & 3.7 & B 1723 & - & 1 \\
\hline 17 & Bazzi & $45^{\circ} 00^{\prime} 41^{\prime \prime}$ & $10^{\circ} 17^{\prime} 04^{\prime \prime}$ & 4350 & 7.5 & 1951 & 1 & - \\
\hline 18 & Motta & $45^{\circ} 03^{\prime} 07^{\prime \prime}$ & $10^{\circ} 15^{\prime} 23^{\prime \prime}$ & 2230 & 4.0 & $1723-1869$ & 1 & 1 \\
\hline 19 & Cascina Ronchetto & $45^{\circ} 02^{\prime} 01^{\prime \prime}$ & $10^{\circ} 14^{\prime} 27^{\prime \prime}$ & 4150 & 4.8 & $1723-1871$ & - & - \\
\hline 20 & Rita & $45^{\circ} 03^{\prime} 10^{\prime \prime}$ & $10^{\circ} 14^{\prime} 31^{\prime \prime}$ & 5370 & 5.0 & B 1723 & - & - \\
\hline 21 & Bicocca & $45^{\circ} 02^{\prime} 52^{\prime \prime}$ & $10^{\circ} 13^{\prime} 41^{\prime \prime}$ & 1980 & 2.5 & 1723 & - & - \\
\hline 22 & Pescaroli Ovest & $45^{\circ} 02^{\prime} 46^{\prime \prime}$ & $10^{\circ} 11^{\prime} 41^{\prime \prime}$ & 2640 & 5.9 & $1723-1871$ & 1 & - \\
\hline 23 & Pescaroli Est & $45^{\circ} 02^{\prime} 41^{\prime \prime}$ & $10^{\circ} 11^{\prime} 49^{\prime \prime}$ & 3090 & 5.5 & $1723-1871$ & 1 & 1 \\
\hline 24 & Sabbie & $45^{\circ} 00^{\prime} 25^{\prime \prime}$ & $10^{\circ} 19^{\prime} 37^{\prime \prime}$ & 2200 & 1.4 & B 1723 & - & - \\
\hline
\end{tabular}

F, presence (1) and absence (-) of fish in study sites; C, presence (1) and absence (-) of Chaoborus larvae in study sites, B 1723 in column Age mean that pond originated before year 1723. 
of the gene coding for the NADH dehydrogenase subunit 5 (ND5). To assess the hybrid origin of specimens from $D$. pulex complex, we used two nuclear protein-coding loci: Rab4 (subunit gene of the GTPase family) and $L d h A$ (lactate dehydrogenase A).

Total genomic DNA was extracted from Daphnia stored in 95\% ethanol using the QIAGEN DNeasy Tissue Kit (Valencia, CA). Parts of two mitochondrial genes, $12 \mathrm{~S}$ $r R N A$ and ND5, were amplified and sequenced with published primers in accordance with the PCR conditions described by Taylor et al. (1996) and Dufresne et al. (2011), respectively. The entire $L d h A$ gene and a part of the gene coding the small GTPase Rab4 were amplified and sequenced according to Marková et al. (2013) and Omilian et al. (2008), respectively. All nucleotide sequence data from the present study have been deposited in the GenBank database under accession numbers KY196420 KY196435 (12S rRNA), KY196436 - KY196439 (Rab4) and KY196440 (LdhA).

Altogether, we analysed 54 individuals from fourteen localities in the Po river Basin for mitochondrial $12 \mathrm{~S}$ $r R N A$ phylogeny and an additional 63 sequences from GenBank (Supplementary Tab. 1) were used to provide wider phylogenetic framework for our study. After we identified the specimens as $D$. pulex mtDNA type on the basis of $12 S r R N A$ phylogeny, we directly amplified and sequenced mitochondrial ND5 gene of 14 individuals from 3 populations. Additionally, we analysed the sequences of two nuclear genes (the Rab4; the $L d h A$ ) of eight individuals from three populations possessing $D$. pulex mtDNA.

The 12S rRNA sequences were used to estimate the nucleotide diversity Pi (Nei, 1987; Nei and Miller, 1990) within Daphnia groups (Tab. 2) by using DnaSP software (Librado and Rozas, 2009). Phylogenetic analyses using maximum-likelihood (ML) criterion were performed in MEGA software version 6 (Tamura et al., 2013). Firstly, we reconstructed mitochondrial phylogenies of $12 \mathrm{~S} \mathrm{rRNA}$ and ND5 by employing $\mathrm{T} 92+\mathrm{G}+\mathrm{I}$ (Tamura 92) and HKY+I (Hasegawa et al., 1985) substitution models selected according to the Bayesian information criterion (BIC), respectively. Then we applied ML criterion to reconstruct nuclear phylogeny of Rab4 and $L d h A$ by using T92 and T92 with gamma distribution substitution models, respectively. Bootstrap support estimated from 1000 replicates using NNI (nearest neighbour interchange) branch swapping algorithm was applied in all phylogenetic analyses.

\section{RESULTS}

Altogether, we identified five Daphnia species in fourteen of 24 analysed pools and ponds (Tab. 3). In 10 sites, no water fleas belonging to the genus Daphnia were found. The presence or the absence of Daphnia is not affected by the presence or the absence of vertebrate or invertebrate predators (Contingency coefficient $=0.098$,

Tab. 2. Genetic diversity within species.

\begin{tabular}{|c|c|c|c|c|c|c|}
\hline & Population & $\begin{array}{l}\text { Sample } \\
\text { size }\end{array}$ & $\begin{array}{l}\text { Number of } \\
\text { haplotypes }\end{array}$ & $\begin{array}{c}\text { Polymorphic } \\
\text { sites }\end{array}$ & $\begin{array}{c}\text { Haplotype } \\
\text { diversity } \pm \text { SD }\end{array}$ & $\begin{array}{c}\text { Nucleotide } \\
\text { diversity } \pm \text { SD }\end{array}$ \\
\hline \multicolumn{7}{|l|}{ D. ambiqua } \\
\hline $12 S r R N A$ & All & 8 & 5 & 24 & $0.786 \pm 0.151$ & $0.01491 \pm 0.00454$ \\
\hline $12 S r R N A$ & Po River Basin & 1 & 1 & NA & NA & NA \\
\hline \multicolumn{7}{|l|}{ D. curvirostis } \\
\hline $12 S r R N A$ & All & 17 & 6 & 6 & $0.647 \pm 0.120$ & $0.00228 \pm 0.00068$ \\
\hline $12 S r R N A$ & Po River Basin & 12 & 4 & 3 & $0.682 \pm 0.102$ & $0.00180 \pm 0.00042$ \\
\hline \multicolumn{7}{|l|}{ D. longispina } \\
\hline $12 S r R N A$ & All & 26 & 13 & 17 & $0.855 \pm 0.056$ & $0.00527 \pm 0.00090$ \\
\hline \multirow[t]{2}{*}{$12 S r R N A$} & Po River Basin & 18 & 5 & 84 & $0.693 \pm 0.086$ & $0.02077 \pm 0.01624$ \\
\hline & Po River Basin without lineage $\mathrm{V}$ & 17 & 4 & 4 & $0.654 \pm 0.089$ & $0.00205 \pm 0.00059$ \\
\hline $12 S r R N A$ & Lineage V & 3 & 2 & 20 & $0.667 \pm 0.09877$ & $0.02874 \pm 0.01355$ \\
\hline \multicolumn{7}{|l|}{ D. obtusa } \\
\hline $12 S r R N A$ & All & 13 & 8 & 71 & $0.808 \pm 0.113$ & $0.04561 \pm 0.01345$ \\
\hline $12 S r R N A$ & Po River Basin & 8 & 3 & 2 & $0.464 \pm 0.200$ & $0.00104 \pm 0.00049$ \\
\hline \multicolumn{7}{|l|}{ D. pulex } \\
\hline $12 S r R N A$ & All & 14 & 5 & 6 & $0.505 \pm 0.158$ & $0.00370 \pm 0.00118$ \\
\hline $12 S r R N A$ & Po River Basin & 10 & 1 & NA & NA & NA \\
\hline$L d h A$ & All & 30 & 13 & 19 & $0.989 \pm 0.031$ & $0.00379 \pm 0.00042$ \\
\hline$L d h A$ & Po River Basin & 16 & 1 & NA & NA & NA \\
\hline Rab4 & All & 22 & 8 & 7 & $0.805 \pm 0.069$ & $0.00397 \pm 0.00049$ \\
\hline Rab4 & Po River Basin & 16 & 4 & 6 & $0.708 \pm 0.091$ & $0.00411 \pm 0.00062$ \\
\hline
\end{tabular}


$\chi^{2}=0.235, \mathrm{df}=1, \mathrm{P}=0.628$ ). Daphnia species from each sampling site were firstly morphologically determined and then verified by molecular analyses. Among 54 analysed individuals, D. ambigua Scourfield, 1947, D. curvirostris Eylmann, 1887, D. longispina, D. obtusa Kurz, 1874 and D. pulex were determined (Tab. 3). The most frequent species, $D$. curvirostris and D. longispina, were found in six and five ponds, respectively. In contrast, D. ambigua was identified only in one pond (Pastore IV) while $D$. obtusa and $D$. pulex were detected in three ponds (Tab. 3). Three Daphnia species (D. longispina, D. curvirostris and D. obtusa) were identified in the pond Sabbie. Additionally, coexistence of $D$. pulex with $D$. longispina was found in three ponds (Pastore I, Pastore III and Bosco Valloni) and coexistence of $D$. curvirostris with $D$. obtusa in the pond Bosco Valloni (Tab. 3).

The D. longispina group was the most genetically variable group in the sampling area where we identified five unique $12 S r R N A$ haplotypes (DLONG A, B, C, D and E; Fig. 2 and Tab. 3). Nucleotide diversity of $D$. longispina from Cremona area was 0.02077 (Tab. 2). However, once we excluded the most divergent haplotype within this group (DLONG E), nucleotide diversity decreased to 0.00205 . To reveal the phylogenetic origin of this haplotype, we included into the phylogenetic analyses also sequences of several divergent lineages of the $D$. longispina complex (Ishida et al., 2011; Petrusek et al., 2012; for details see Supplementary Tab. 1). Interestingly, the haplotype DLONG E clustered together with two individuals from the Pechora delta (northern European Russia) and formed the clade $\mathrm{V}$ of $D$. longispina complex (named by Petrusek et al., 2012).

Altogether, four $12 S r R N A$ haplotypes of $D$. curvirostris group were identified in the study area (DCUR A, B, C and D; Fig. 2 and Tab. 3). Interestingly, in the temporary pond located close to the pond Pastore III, different $12 S$ rRNA haplotypes were found in 2014 and 2015. In 2015, the dominant haplotype DCUR C was replaced there by a new haplotype DCUR D. This is the sole case of shift in genetic variability between years within $D$. curvirostis group. In ponds Bosco Valloni and Sabbie, where D. curvirostris coexists with $D$. obtusa and with $D$. longispina and D. obtusa, respectively, only the most common haplotype DCUR C was identified. Even though the nucleotide diversity of $D$. curvirostris from the study area was low (0.00180), overall nucleotide diversity of $D$. curvirostris group was just a little bit higher (0.00228; Tab. 3).

D. obtusa inhabited four pounds in the study area and within the D. obtusa group three $12 S r R N A$ haplotypes were identified (DOBT A, B, and C; Fig. 2 and Tab. 3). The nucleotide diversity of $D$. obtusa from the study area was the lowest one (0.00104) within all analysed Daphnia groups, while total nucleotide diversity of the D. obtusa group was relatively high $(0.04651$; Tab. 2$)$.

The pond Pastore IV was the only locality in the study area where we found $D$. ambigua in two years sampling period (2014 and 2015). The D. ambigua we identified shared $12 S r R N A$ haplotype (DAMB A) with individuals from France and USA (Fig. 2).

D. pulex was found in three ponds (Pastore III, Pastore I and Forche) during our sampling in 2014 and 2015 (Tab. 3). Altogether 12 individuals were analysed and genetically determined as European D. pulex (Fig. 2, Supplementary Figs. 1 and 2). All individuals carried unique haplotype (DPX A) at both mitochondrial genes $(12 \mathrm{~S}$ $r R N A$ and ND5) and clustered into the European D. pulex clade. Additional analyses of two nuclear genes ( $L d h A$ and Rab4) revealed that $D$. pulex from the study area carried only European $D$. pulex haplotypes at both analysed nuclear markers (Supplementary Figs. 1 and 2). All eight

Tab. 3. Distribution of haplotype diversity within sampling sites included in this study.

\begin{tabular}{llll}
\hline Species & Haplotype & GenBank Accession N. & Sampling site \\
D. ambigua & DAMB A & KY196426 & Pastore IV \\
\hline D. curvirostris & DCUR A & KY196435 & Isola Pescaroli East \\
& DCUR B & KY196428 & San Giorgio, Bicocca \\
& DCUR C & KY196425 & T. Pond, Bosco Valloni, Sabbie \\
& DCUR D & KY196432 & T. Pond \\
\hline D. longispina & DLONG A & KY196434 & Vecchio \\
& DLONG B & KY196431 & Sabbie \\
& DLONG C & KY196423 & Pastore III \\
& DLONG D & KY196424 & Pastore I, Bosco Piazza, Sabbie \\
\hline D. obtusa & DLONG E & KY196433 & Bosco Piazza \\
& DOBT A & KY196427 & Bosco Valloni, Martignana \\
& DOBT B & KY196430 & Sabbie \\
\hline D. pulex & DOBT C & KY196429 & Isola Pescaroli West \\
\hline
\end{tabular}

T., temporary. 
European D. pulex were homozygote at the $L d h A$ gene and shared the LdhA haplotype DPX A (Supplementary Fig. 2). Higher genetic variability was found at a second nuclear gene the Rab4 (Supplementary Fig. 2). Altogether, we identified four Rab 4 haplotypes (haplotypes DPX A, DPX B, DPX C and DPX D) among individuals from the study area with nucleotide diversity equal to 0.00411. While two Rab4 haplotypes (DPX B and DPX C; Supplementary Fig. 2) were determined as unique for the Cremona region, two other Rab4 haplotypes (DPX A and DPX D) were shared by individuals from Czech Republic, Sweden, Germany, Lithuania and United Kingdom (Supplementary Fig. 2).

\section{DISCUSSION}

In this study, we have sampled 24 pools and ponds that covered $200 \mathrm{~km}^{2}$ area of the Po river Basin in Cremona province. By using diagnostic genetic markers, we assessed

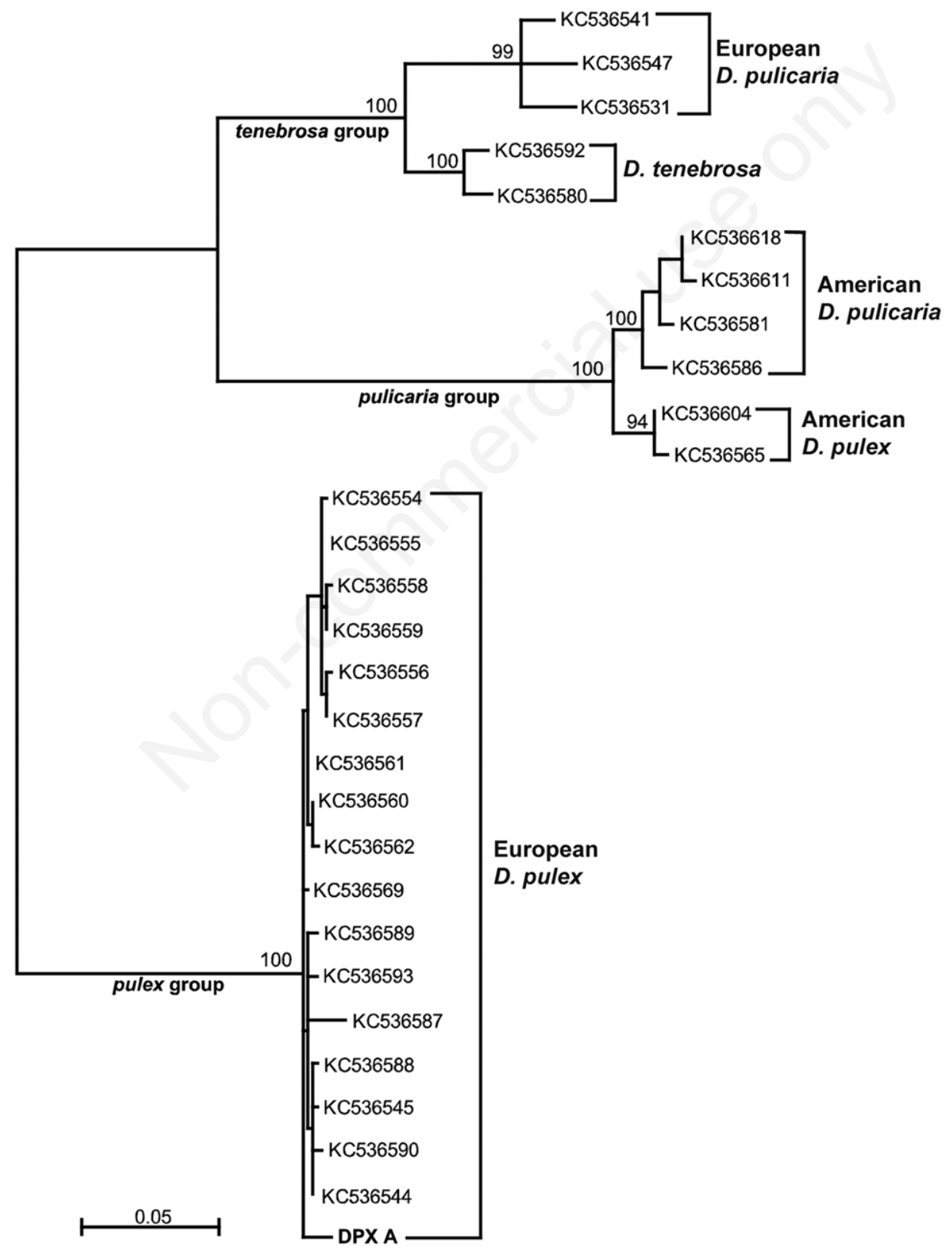

Fig. 2. Maximum likelihood mitochondrial phylogeny based on ND5 haplotypes. Numbers along branches indicate the percent bootstrap frequencies for bipartitions with greater than $70 \%$ support. 
the presence of five Daphnia species (D. ambigua, D. curvirostris, D. longispina, D. obtusa and D. pulex) in a relatively small area of the Po river Basin intensively devoted to agricultural activities and vulnerable to diffuse pollution. We discuss these results in wider phylogenetic context.

In the 70's, D. pulex was identified in the Po river Basin (Caorso and Ozzano dell'Emilia, about $50 \mathrm{~km}$ west and 100 $\mathrm{km}$ east from our study area, respectively) by Margaritora (personal communication), however no information about its origins was reported. Firstly, we recorded D. pulex in the pond Pastore III in 2011 (Rossi et al., 2014) and later we extended our sampling and focused on phylogenetic origin of those Daphnia species that could pose a threat for local populations. A well-known invasive asexual clone of $D$. pulex has spread from North America and replaced the native one throughout Africa, Spain (Mergeay et al., 2006) and recently has been also recorded in Sardinian reservoir (Sardinia Island; Fadda et al., 2011) and in Avigliana Lake (Piedmont Region, Northern Italy; Vergilino et al., 2011; Crease et al., 2012; Marková et al., 2013) that is only about $200 \mathrm{~km}$ west from our study area. Because of that, the chance that this highly invasive clone could be present also in the Po river Basin was high. Phylogenetic analyses of several individuals from the Po river Basin, morphologically determined as $D$. pulex, revealed that $D$. pulex from the study area is true European D. pulex (Fig. 3; Supplementary Figs. 1 and 2). While mitochondrial haplotypes of $12 S r R N A$ and $N D 5$ genes were carried only by individuals from the Po river Basin, nuclear $L d h A$ and Rab4 haplotypes were shared also by D. pulex from the Czech Republic, Sweden, Germany, Lithuania and United Kingdom with exception of two unique Rab4 haplotypes for the Po river Basin (DPX B and C; Supplementary Fig. 2). Even though the low genetic variability was identified at most of the analysed loci, the presence of adult males, ephippial females and free ephippia indicate that the population of $D$. pulex from the Po river Basin reproduce by cyclical parthenogenesis, and so clearly differ also by reproductive strategy from invasive asexual clone inhabited Sardinian reservoirs and Lake Avigliana (Rossi et al., 2014). Additional analyses of tens of D. pulex from the study area could reveal some genetic diversity also at the mitochondrial genes.

D. ambigua was the only invasive Daphnia species in the Po river Basin, and belongs to the North-Eastern American strain that was introduced by long-distance dispersal and is spreading across Europe (Hebert et al., 2003). We determined D. ambigua only in one of 24 studied ponds (Pastore IV) which is located in the core of our sampling area. However, this Daphnia species is very successful in spreading because of small body size, which makes it preadapted to eutrophied ponds that are over-stocked with fish (De Meester et al., 2002). In Belgium (Lake Donk, Eastern Flanders), D. ambigua was recorded for the first time in the 60's by Dumont (1974). By 2002 it was already widespread in Flanders (De Meester et al., 2002). Even though D. ambigua was recorded in England (Johnson, 1952), France (Amoros, 1980), Germany (Krause-Dellin, 1992; Maier and Buchholz, 1996) and Czech Republic (Hamrová and Černý, 2007), the only available European $12 S r R N A$ sequences in GenBank database are from France (Schwenk et al., 2000; Hebert et al., 2003). We showed that D. ambigua haplotype from the Po river Basin (DAMB A) is identical with haplotypes from France (AF277283, AF523738) and New York (USA; AF523735; Fig. 3). The rapid colonization of Europe by D. ambigua and the occupancy of large blocks of territory by a single haplotype support little genetic diversity in the early phases after colonization of a new continent (De Meester et al., 2002). Our record of invasive $D$. ambigua supports well known high dispersal capacity of freshwater cladocerans inhabiting island-like aquatic habitats (Slusarczyk and Pietrzak, 2008). In fact, $D$. ambigua has been already recorded in Northern Italy (Margaritora, 1985; Manca et al., 2005) and in Sicily (Marrone et al., 2005) but no information about its origin was reported. Manca et al. (2005) recorded D. ambigua only in the Lago di Mantova superiore that is less than 50 $\mathrm{km}$ east from our study area. D. ambigua from Lago di Endine (Northern Italy) was not cyclomorphic and showed some morphological characters that differentiated it from other European populations (Margaritora, 1985). D. ambigua from the pond Pastore IV seems cyclomorphic, showing a small pointed helmet, and does not have the ocello (Rossi; personal observation). Dispersal potential of D. ambigua is enormous and will require monitoring, because this small invasive species could pose a threat to native Daphnia populations in the Po river Basin where eutrophication and fish presence made local water bodies suitable for it.

In the Po river Basin, we found a high genetic diversity within the $D$. longispina complex (five haplotypes with Pi 0.02077). Between 2011 and 2014, D. pulex dominated in the pond Pastore III while in 2015 it was partly replaced by D. longispina (Rossi et al., 2015; Rossi et al., in preparation). Due to high population fluctuation and spatial/temporal dispersal by resting eggs, D. longispina could have colonized the pond Pastore III from surrounding ponds. An alternative scenario is that D. longispina have been present in the pond Pastore III already before, but in low hardly detectable density and/or in ephippial eggs bank, or could colonized this pond recently by long distance dispersal from other sources (e.g. some introductions by huntsmen, by fishers, by vehicles, by migrant birds). Interestingly the haplotype DLONG E, carried by Daphnia from the pond Bosco Piazza, clustered into the highly divergent clade $\mathrm{V}$ of $D$. longispina complex (named by Petrusek et al., 2012) together with two individuals from Pechora Delta (northern European Russia). However, $12 S$ rRNA haplo- 
types (JX069356, JX069357) carried by individuals from Pechora Delta are distinct from the Po river Basin one (nucleotide diversity 0.02874 ) that negotiates a scenario of recent invasion. Instead of that, our phylogenetic data suggested that the clade $\mathrm{V}$ of $D$. longispina complex is not restricted only to northern European Russia but has a much wider area of distribution. Daphnia from the pond Bosco Piazza (DLONG E, Fig. 3) likely represents a distinct biological species. Because this putative new species co-exists in the pond Bosco Piazza with D. longispina, sequencing of additional marker(s) with focus on hybridization will be required.

An additional two Daphnia species (D. curvirostris and D. obtusa) with low nucleotide diversity (0.00180 and

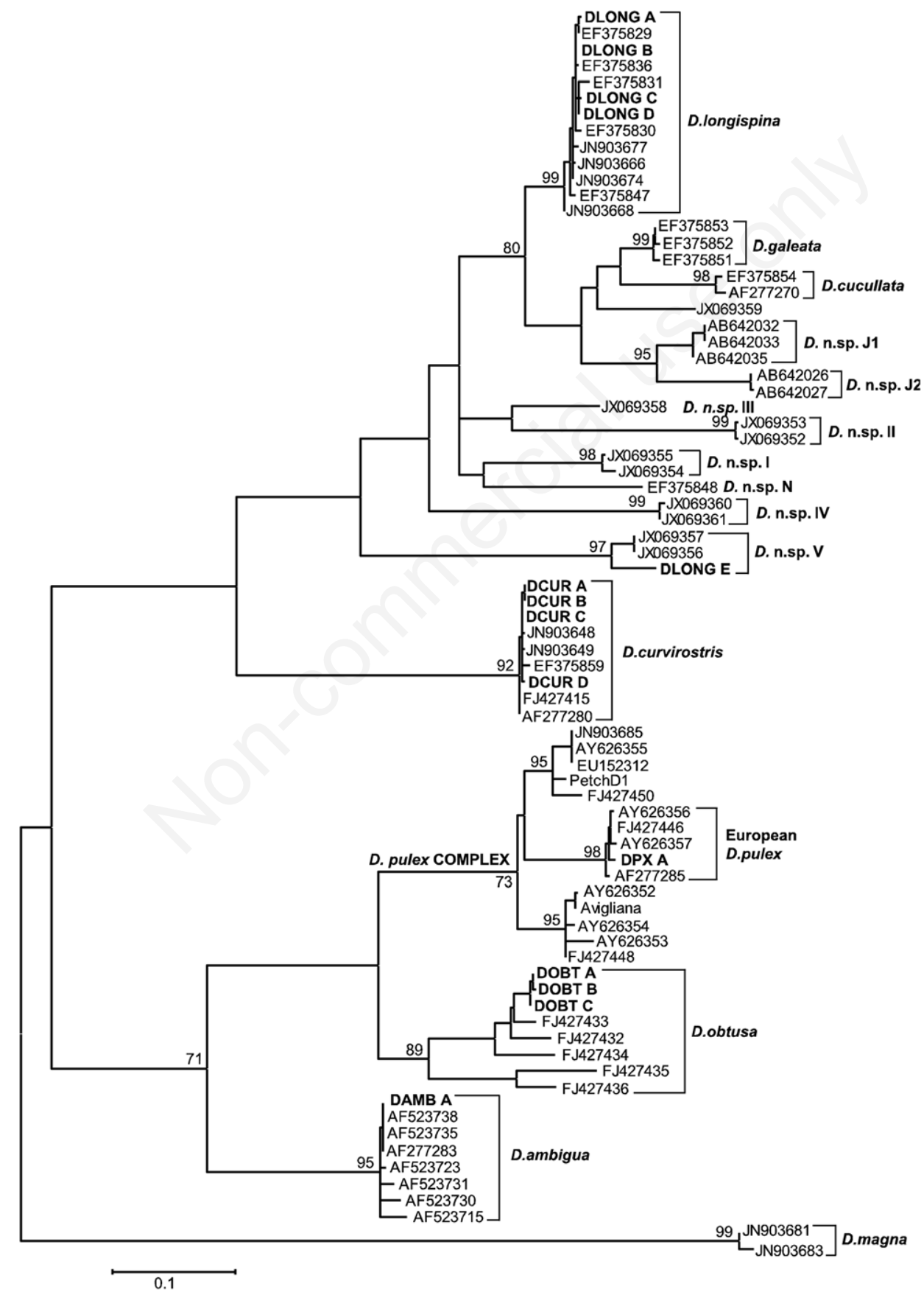

Fig. 3. Maximum likelihood mitochondrial phylogeny based on $12 S r R N A$ haplotypes. Numbers along branches indicate the percent bootstrap frequencies for bipartitions with greater than $70 \%$ support. 
0.00104) inhabited six and four ponds in the study area, respectively. Generally, low genetic variability within whole $D$. curivirostris group (nucleotide diversity 0.00228 ) containing D. curvirostris from Europe (JN903648, JN903649) and from Canada (FJ427415, AF277280; Fig. 3) was detected. The D. obtusa clade involved two groups, one formed by D. obtusa from Europe including study area and the other by D. obtusa from North America. Phylogenetic analyses showed that both Daphnia species from the Po river Basin have European origin.

The finding of five Daphnia species in a relatively small area $(20,000 \mathrm{ha})$ of the Po river Basin is in accordance with previous studies at the regional scale and from different parts of Europe. The analysis of Cladocera community including 29 lakes in the Po River watershed during the period 1998-1999 revealed the presence of five Daphnia species (D. longispina, D. ambigua, D. hyalina, D. galeata and $D$. cucullata) and four relative hybrids (Manca et al., 2005). Between November 1987 and May 1989, during a study focused on distribution and genetic variability of $D$. obtusa, in 97 ponds and pools sampled in the Po river catchment (Parma province), Bachiorri found four Daphnia species (D. obtusa, D. longispina, D. ambigua and D. hyalina) in 18 sampling sites (Bachiorri et al., 1991 and unpublished data). In 25 temporary ponds located in a wetland zone spread over an area of 180,000 ha in Doñana (South-west Spain) 3 species of Daphnia (D. longispina, D. magna and D. pulex) were found (Frish et al., 2006). In 33 interconnected shallow ponds in a small area (200 ha) in Belgium, 3 species, D. pulex, D. ambigua and D. galeata were recorded (Cottenie et al., 2001).

\section{CONCLUSIONS}

Here we identified phylogenetic origin of five Daphnia species from Cremona province and showed that four of them are native European species. Until now, only the D. ambigua invasive species in the Po River Basin was found. In addition, we identified, within the $D$. longispina complex, a highly divergent haplotype that clustered together with individuals from northern European Russia and might represent a distinct biological species. This finding has important implication for biodiversity conservation in agricultural areas. Future attention will require monitoring of the dispersal of North American D. pulex which presents a high risk for natural populations in the Po River Basin.

\section{ACKNOWLEDGMENTS}

We thank Petr Kotlík for his support, R. Siegert for English revision, and two anonymous reviewers for their constructive comments, which helped us to improve the manuscript. Additional institutional support RVO 67985904 was provided to S. Marková.

\section{REFERENCES}

AAVV, 1999. [Appunti sulla Golena del Po. Le lanche di Motta Baluffi e Torricella del Pizzo]. [Book in Italian]. Mus. Civ. St. Nat. Cremona, Quaderno 4.

Amoros G, 1980. [Observations morphologiques et écologiques sur Daphnia ambigua Scourfield, 1946 (Cladocera), espèce nouvelle pour la France].[Article in French]. Crustaceana 39:247-254.

Bachiorri A, Rossi V, Bonacina C, Menozzi P, 1991. Enzymatic variability of a colonizing population of Daphnia obtusa Kurz (Crustacea, Cladocera) in lake Orta (Italy). Verh. Internat. Verein. Limnol. 24:2813-2815.

Bassanino M, Sacco D, Zavattaro L, Grignani C. 2011. Nutrient balance as a sustainability indicator of different agro-environments in Italy. Ecol. Indic. 11:715-723.

Belfiore N, Anderson SI, 2001. Effects of contaminants on genetic patterns in aquatic organisms: a review. Mutat. Res. 489:97-122.

Colbourne JK, Crease TJ, Weider LJ, Hebert PDN, Dufresne F, Hobaek A, 1998. Phylogenetics and evolution of a circumarctic soecies complex (Cladocera: Daphnia pulex). Biol. J. Linn. Soc. 65:347-365.

Cottenie K, Nuytten N, Michels E, De Meester L, 2001. Zooplankton community structure and environmental conditions in a set of interconnected ponds. Hydrobiologia 442:339-350.

Crease TJ, Omilian AR, Costanzo KS, Taylor DJ, 2012. Transcontinental phylogeography of the Daphnia pulex species complex. PLoS One 7:e46620.

De Meester L, Gomez, A, Okamura B, Schwenk K, 2002. The Monopolization Hypothesis and the dispersal-gene flow paradox in aquatic organisms. Acta Oecol. 23:121-135.

De Meester L, Declerck S, Stoks R, Louette G, Van De Meutter F, De Bie T, Michels E, Brendonck L, 2005. Ponds and pools as model systems in conservation biology, ecology and evolutionary biology. Aquatic Conserv: Mar. Freshw. Ecosyst. 15:715-725.

Downing JA, 2010. Emerging global role of small lakes and ponds: little things mean a lot. Limnetica 29:9-24.

Dudgeon D, Arthington AH, Gessner MO, Kawabata ZI, Knowler DJ, Lévêque C, Naiman RJ, Prieur-Richard A-H, Soto D, Stiassny MLJ, Sullivan CA, 2006. Freshwater biodiversity: importance, threats, status and conservation challenges. Biol. Rev. 81:163-182.

Dufresne F, Marková S, Vergilino R, Ventura M, Kotlík P, 2011. Diversity in the reproductive modes of European Daphnia pulicaria deviates from the geographical parthenogenesis. PLoS OneE 6:e20049.

Dumont HJ, 1974. Daphnia ambigua Scourfield, 1947 (Cladocera: Daphnidae) on the European continent. BioL Jaarb Dodonaea 42:112-116.

Fadda A, Marková S, Kotlík P, Lugliè A, Padedda B, Buscarin, P, Sechi N, Manca M, 2011. First record of planktonic crustaceans in Sardinian reservoirs. Biologia 66:856-865.

Feld CK, Birka S, Emeb D, Gerischc M, Heringa D, Martin Kernand M, Mailehte K, Mischkef U, Otte I, Pletterbauerg F, 
Poikaneh S, Salgadod J, Sayerd CD, vanWicheleni J, Malard F, 2016. Disentangling the effects of land use and geo-climatic factors on diversity in European freshwater ecosystems. Ecol. Indic. 60:71-83.

Feuchtmayr H, Moran R, Hatton K, Connor L, Heyes T, Moss B, Harvey I, Atkinson D, 2009. Global warming and eutrophication: effects on water chemistry and autotrophic communities in experimental hypertrophic shallow lake mesocosms. J. Appl. Ecol. 46:713-723.

Frish D, Moreno-Ostos E, Green AJ, 2006. Species richness and distribution of Copepods and Cladocerans and their relation to hydroperiod and other environmental variables in Doñana, South-west Spain. Hydrobiologia 556:327-340.

Hamrová E, Černý M, 2007. [Invazní preloočky Daphnia ambigua a Daphnia parvula v Průhonicích], p 36. In: Bryja J, Zukal J, Řehák Z (eds), [Zoologické dny Brno 2007]. [Conference Articles in Czech].Sborník abstraktů z konference 8.-9. února 2007. Ústav biologie obratlovců AV ČR, Brno.

Hasegawa M, Kishino H, Yano T, 1985. Dating of the humanape splitting by a molecular clock of mitochondrial DNA. J. Mol. Evol. 22:160-174.

Hebert PDN, Wilson CC, 1994. Provincialism in plankton: endemism and allopatric speciation in Australian Daphnia. Evolution 48:1333-1349.

Hebert PDN, Witt JDS, Adamowicz SJ, 2003. Phylogeographical patterning in Daphnia ambigua: regional divergence and intercontinental cohesion. Limnol. Oceanogr. 48:261-268.

Hunter K, Pyle G, 2004. Morphological response of Daphnia pulex to Chaoborus americanus kairomone in the presence and absence of metals. Envrion. Toxicol. Chem. 23:1311-1316.

Ishida S, Takahashi A, Matsushima N, Yokoyama J, Makino W, Urabe J, Kawata M, 2011. The long-term consequences of hybridization between the two Daphnia species, $D$. galeata and D. dentifera, in mature habitats. BMC Evol. Biol. 11:209.

Johnson JDS, 1952. The British species of the genus Daphnia (Crustacea, Cladocera). Proc. Zool. Soc. London 122:435-462.

Krause-Dellin D, 1992. Erster Nachweis von Daphnia parvula Fordyce 1901 und Daphnia ambigua Scourfield 1946 (Crustacea, Cladocera) für das Einzugsgebiet der Donau. Lauterbornia 9:19-25.

Landkildehus F, Søndergaard M, Beklioglu M, Adrian R, Angeler DG, Hejzlar J, Papastergiadou E, Zingel P, Çakiroğlub AI, Scharfenberger U, Drakare S, Nõges T, Sorf M, Stefanidis K, Tavşanoğlu Ü N, Trigal C, Mahdy A, Papadaki C, Tuvikene L, Larsena SE, Kernan M, Jeppesen E, 2014. Climate change effects on shallow lakes: design and preliminary results of a cross-European climate gradient mesocosm experiment. Est. J. Ecol. 63:71-89.

Librado P, Rozas J, 2009. DnaSP v5: A software for comprehensive analysis of DNA polymorphism data. Bioinformatics 25:1451-1452.

Loh J, Wackernagel M (eds), 2004. Living Planet Report 2004. World-Wide Fund for Nature International (WWF), Global Footprint Network, UNEP World Conservation Monitoring Centre, Gland, Switzerland.

Maier G, Buchholz R, 1996. Zooplankton communities of gravel pits in relation to trophy, dredging activity and macrophyte growth. Limnologica 26:353-360.

Manca M, Margaritora F, De Bernardi R, 2005. Comunità a cladoceri di laghi del Bacino del Po: risultati ottenuti nell'ambito del Progetto Europeo Long distance dispersal of Aquatic KEy Species (LAKES). Biol. Ambient. 19:17-24.

Margaritora GF, 1985. [Cladocera. Fauna d'Italia.] [Book in Italian]. Calderini, Bologna.

Marková S, Dufresne F, Manca M, Kotlík P, 2013. Mitochondrial capture misleads about ecological speciation in the Daphnia pulex complex. PLoS One 8:e69497.

Marrone F, Barone R, Naselli-Flores L, 2005. Cladocera (Branchiopoda: Anamopoda, Ctenopoda and Onychopoda) from Sicilian inland waters: an update inventory. Crustaceana 78:1025-1039.

Meerhoff M, Clemente JM, Teixeira De Mello F, Iglesias C, Pederse AR, Jeppesen E, 2007. Can warm climate-related structure of littoral predator assemblies weaken the clear water state in shallow lakes? Glob. Change Biol. 13:1888-1897.

Mergeay J, Verschuren D, De Meester L, 2006. Invasion of an asexual American water flea clone throughout Africa and rapid displacement of a native sibling species. Proc. R Soc. B 273:2839-2844.

Mitchell SE, Rogers ES, Little TJ, Read AF, 2005. Host-parasite and genotype-by-environment interactions: temperature modifies potential for selection by a sterilizing pathogen. Evolution 59:70-80.

Nei M, 1987. Molecular evolutionary genetics. Columbia Univ. Press, New York: 512 pp.

Nei M, Miller JC, 1990. A simple method for estimating average number of nucleotide substitutions within and between populations from restriction data. Genetics 125:873-879.

Omilian AR, Scofield DG, Lynch M, 2008. Intron presence-absence polymorphisms in Daphnia. Mol. Biol. Evol. 25:21292139.

Petrusek A, Thielsch A, Schwenk K, 2012. Mitochondrial sequence variation suggests extensive cryptic diversity within the Western Palearctic Daphnia longispina complex. Limnol. Oceanogr. 57:1838-184.5.

Pfenning M, Schwenk K, 2007. Cryptic animal species are homogeneously distributed among taxa and biogeographical regions. BMC Evol. Biol. 7:121.

Riessen HP, Linley RD, Altshuler I, Rabus M, Söllradl T, Clausen-Schaumann H, Laforsch C, Yan ND, 2012. Changes in water chemistry can disable plankton prey defences. P. Natl. Acad. Sci. USA 109:15377-15382.

Ripley BJ, Simovich MA, 2009. Species richness on islands in time: variation in ephemeral pond crustacean communities in relation to habitat duration and size. Hydrobiologia 617:181-196.

Rossi V, Maurone C, Benassi G, Ferrari I, 2014. Reproduction of Daphnia pulex in a Northern Italy pond. J. Limnol. 73:459-467.

Rossi V, Maurone C, Benassi G, Marková S, Kotlik P, Bellin N, Ferrari I, 2015. Phenology of Daphnia in a Northern Italy pond during the weather anomalous 2014. J. Limnol. 74:631-638.

Sakamoto M, Chang KH, Hanazato T, 2006. Inhibition of development of antipredator morphology in the small cladoceran Bosmina by an insecticide: impact of an anthropogenic chemical on predator-prey interactions. Freshwater Biol. 51:1974-1983.

Scheffer M, Straile D, van Nes EH, Hosper H, 2001. Climatic 
warming causes regime shifts in lake food webs. Limnol. Oceanogr. 46:1780-1783.

Schwenk K, Posada D, Hebert PDN, 2000. Molecular systematics of European Hyalodaphnia: the role of contemporary hybridization in ancient species. Proc. R. Soc. Lond. B 267:1833-1842.

Slusarczyk M, Pietrzak B, 2008. To sink or float: the fate of dormant offspring is determined by maternal behaviour in Daphnia. Freshwater Biol. 53:569-576.

Taylor DJ, Hebert PDN, Colbourne JK, 1996. Phylogenetics and evolution of the Daphnia longispina group (Crustacea) based on 12S rDNA sequence and allozyme variation. Mol. Phylogenet. Evol. 5:495-510.
Tamura K, Stecher G, Peterson D, Filipski A, Kumar S, 2013. MEGA6: Molecular Evolutionary Genetics Analysis Version 6.0. Mol. Biol. Evol. 30:2725-2729.

Vadadi-Fülöp C, Hufnagel L, 2014. Climate change and plankton phenology in freshwater: current trends and future commitments. J. Limnol. 73:1-16.

Vadadi-Fülöp C, Sipkay C, Mészáros G, Hufnagel L, 2012. Climate change and freshwater zooplankton: what does it boil down to? Aquat. Ecol. 46:501-519.

Vergilino R, Marková S, Ventura M, Manca M, Dufresne F, 2011. Reticulate evolution of the Daphnia pulex complex as revealed by nuclear markers. Mol. Ecol. 20:1191-1207. 